DOI: 10.20472/BMC.2019.010.003

\title{
KATARÍNA ČULKOVÁ
}

Technical University of Košice, Slovakia

MÁRIA JANOŠKOVÁ

Technical University of Košice, Slovakia

ADRIANA CSIKÓSOVÁ

Technical University of Košice, Slovakia

\section{PREDICTION OF TOURISM IN THE SUSTAINABLE DEVELOPMENT OF CARPATIAN REGION}

\begin{abstract}
:
Tourism records considerably massive development as a single sector and its development can be contribution only in case it is in accord with the living environment and social acceptance. The goal of the contribution is to search sustainable development in area of tourism in the frame of Visegrad group visitors in Slovakia in comparing with whole world prediction development. The searching is made by external environment of tourism system, regarding present legislation about tourism support. The evaluation and comparing is done by the index of country attractiveness from the view of satisfied demands of visitors and their country origin. The main results show attractiveness of the Slovakia is considered as attractive country from the view of satisfied demands. By this way, there is confirmed space for visitation increasing as well as improving Slovakia perception as target country for tourism.
\end{abstract}

\section{Keywords:}

Country attractiveness; Development prediction; Sustainability; Tourism; Visegrad group

JEL Classification: F15, 052 


\section{Introduction}

Tourism presents a flexible and complex sector that belongs among most rapidly developing sectors in the whole world economy. Presently tourism has great power to the sustainable development of regions (Petrović et al., 2018). However, tourism development can be contribution only in case it is in accord with the living environment and social acceptance (Das \& Hussain, 2016). Different definitions of sustainability concept are continuously brought up, shaped by each industry or organizational culture. Sustainability is used for example in area of tourism as "green washing", which underwent many redefinitions towards wider aspect of sustainability. Sustainability became agenda, as part of each company missions and objectives statements. (Elkington, 2004).

Due to the mentioned, contribution is orientated to the searching of economic potential and employment in tourism, with regard to social and environmental influence through monitoring of tourism according regional policy and sustainability. However, tourism has interdisciplinary character therefore, there is necessary to make development approach for accepting of the tourism strategy.

\section{Present state of problem solving}

Tourism presents a tool for increasing of living standard, providing social and economic possibilities for all subjects that have interest to use this industry for their favour (Das \& Hussain, 2016). As for the long-term prediction, international movement of tourists would increase worldwide by $3.3 \%$ in $2010-2030$. It presents 1.8 milliard international tourists to 2030 . In 2010 2030 arrivals in developing destinations (increasing by $4.4 \%$ annually) are expected to increase double times against developed economies (increase by $2.2 \%$ annually). Market rate of developing economies from $1980(30 \%)$ to 2014 (45\%) is increased by 15\%, and according mentioned there is prediction to 2030 the number will achieve yet $57 \%$, which is equal more than milliard of international tourists - whole world movement (UNWTO, 2015).

As for the Slovakia, Molokáč et al. (2016) provided strategic research of the market, concluded Slovakia is positively considered as tourism destination, recording improvement of airlines, including new or more flights to still more destinations. Similarly, there is recorded stronger and better propagation of Slovakian tourism, including effective and properly targeted advertisements. Improving of economic conditions in the frame of Slovakian regions is also recorded, which means domestic consumers can afford to go on holiday several times per year. During the last year, tourism recorded worldwide something more travel by airlines. In 2014, 54\% of single day visitors used to travel by airlines to target destinations, while only $39 \%$ of tourists used road transport, $2 \%$ of tourists used railways and $5 \%$ of the tourist used waterways. According mentioned we could predict that this trend will continue also in the next years, and airlines could achieve by this way yet higher values from travelling in comparing with road transport.

Nowadays we faced a wave of sustainable development (Willard \& Elkington, 2002). It is also important within the tourism industry, to tailor indicators since tourists in different market segments can generate varying environmental and social impacts on destinations (Dwyer \& Forsyth, 2008). A review of the existing literature reveals some early attempts to identify meaningful measures of sustainable tourism impact. Dymond (1997) categorized WTO indicators 
into following groups: ecological indicators (site protection, stress, use intensity, waste management and critical ecosystems); social indicators (social impact, local satisfaction); economic indicators (consumer satisfaction and tourism contribution to the local economy); and plan indicators (development control and planning process). Generalized and global sustainable tourism guidelines could be successfully employed at a local level (Stoddard et al., 2012). On the other hand, Hughes (2002) takes a critical perspective on the sustainability of tourism but from a more "technical" or ecological point of view than the critiques of consumer capitalism.

Tourism is influenced also by security situation and migration crisis in the Europe. The localities with low threatening of life are preferred, as well as localities with property and health protection, as well as with low criminality (Pizam \& Smith, 2000). Direct influence, belonging to the tourism development has also education level of inhabitants and strengthening of their relation toward tourism and visitors (Blumenberg, \& Pierce, 2017). Other necessity is development of positive attitude of state representatives, regions, and villages towards visitors (Kock et al., 2016). Also proper presentation of the locality presents important factor of tourism development by using of marketing activities (Borowiecki \& Castiglione, 2014).

There are some studies, orientated to the prediction of the tourism in regions (Liu et al., 2018), but they miss generalization of the results of tourism development for whole country. Tudorache et al. (2017) tried to predict tourism development by European tourism indicators system for sustainable tourism. Moscardo and Murphy (2014) recognized the complexity of tourism. There is still problem with data availability and a need to overcome strategic guidelines and political and theoretical proposals of indicators (as studied by Torres-Delgado \& Saarinen, 2014). However, practical applications for the sustainable development of tourism must be still considered.

\section{Methodology}

During the research we analysed the external environment of tourism system, since subjects of tourism are differently influenced by mutually connected and still developed systems. The main factors are included in Figure 1.

Figure 1: Key factors of external environment of tourism system

\begin{tabular}{|l|l|}
\hline External environment & Key factors \\
\hline Political and legal environment & $\begin{array}{l}\text { political stability, inhabitants and visitors security, business } \\
\text { environment, tourism coordination, legislation of tourism, strategy } \\
\text { and conception for tourism development in the region }\end{array}$ \\
\hline Economic environment & GDP, unemployment, wages and rewards, inflation measure \\
\hline Social environment & $\begin{array}{l}\text { demographic structure of inhabitants, social policy of the state, } \\
\text { health care }\end{array}$ \\
\hline Cultural environment & $\begin{array}{l}\text { education of inhabitants, language skills of inhabitants, inhabitants } \\
\text { attitudes and values }\end{array}$ \\
\hline Technological environment & $\begin{array}{l}\text { road and railway net, water ways length, international and regional } \\
\text { airports, public transport capacity, ICT }\end{array}$ \\
\hline Ecological environment & $\begin{array}{l}\text { protected areas, waste production from tourism activities, water } \\
\text { quality used in tourism, soil erosion in visited areas }\end{array}$ \\
\hline
\end{tabular}

Source: own processing according Molokáč et al. (2016)

During the research, we regarded Law No 91/2010 about tourism support, orientated to the influences of various structures of tourism offer according demand. The Law requests to observe 
quality standards in destinations by correct marketing mix. It means by this way destination could increase its attractiveness.

\subsection{Main indexes of tourism development}

Main assumption for development of staying in target destination is correspondent number of accommodation and catering facilities.

\section{$>$ Evaluation of attractiveness from the view of satisfied demand of visitors}

The coefficient means percentage number of how many people from total population of the market visit given target - ka1, or what annual rate in target place belongs to one night - ka2. By this way the real visit of a destination is compared with potential visits with regard to the volume of the market.

\section{$>$ Evaluation of perceived attractiveness in accord with the country origin of the respondents}

With regard to the individuals, considering chosen target place as attractive, due to the various reasons, familiar, working, economic or others, they do not need to become visitors of the destination, therefore we considered as very important to evaluate attractiveness of analysed countries according to perceived approach that considers potential demand of respondents.

\section{Results}

During the research we evaluated first of all long-term prediction of tourism to 2030 according UNWTO to find out if there is space for tourism improving in Slovakia. First graph at Figure 2 gives considerable potential to the next growth of whole world tourism, while blue graph predicts international tourist inflow in Europe to 2030.

Figure 2: Long-term tourism prediction to 2030

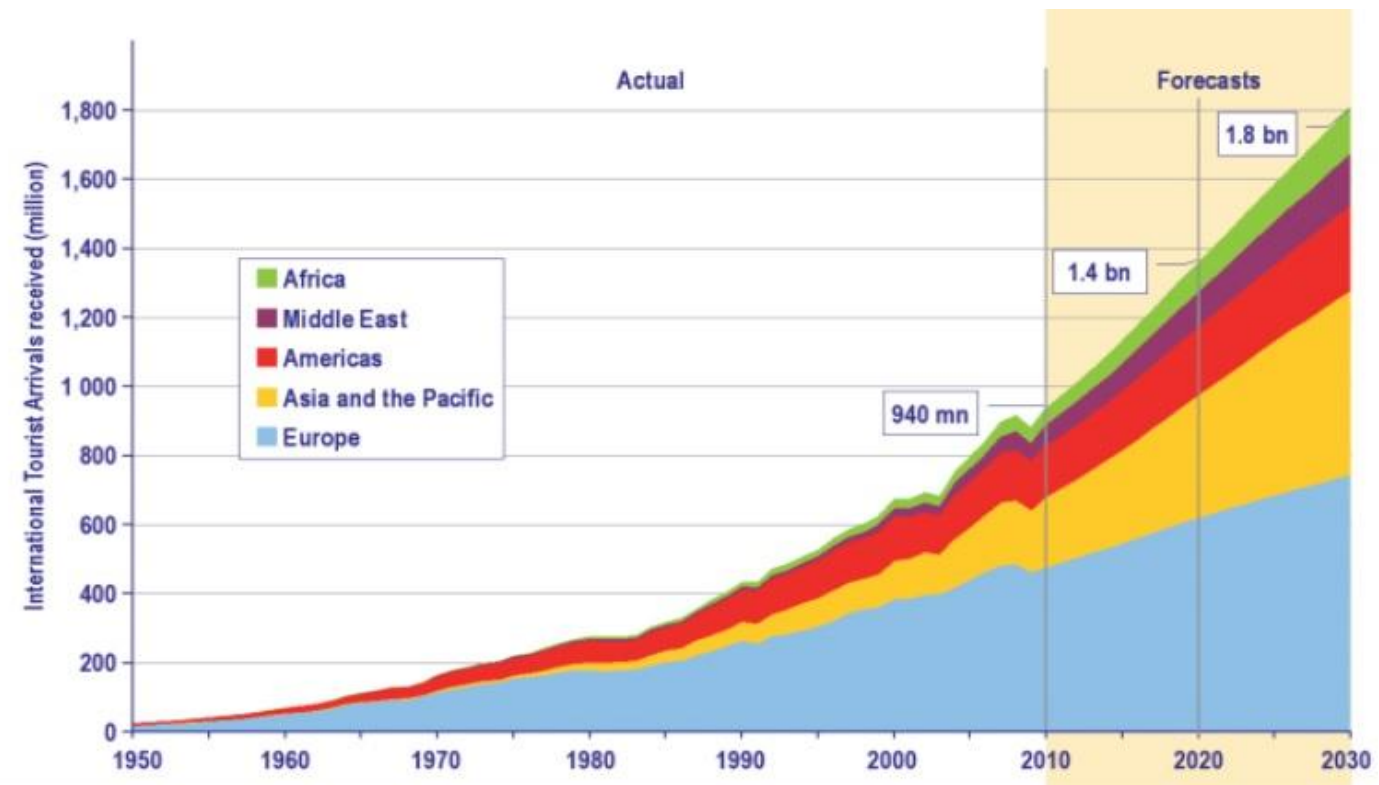

Source: own processing according UNWTO (2014) 
Second graph at Figure 3 illustrates active foreign (whole world) tourism that is recorded from 1980 to assumed development in 2030.

Figure 3: Active foreign tourism according world's regions (in mil. persons)

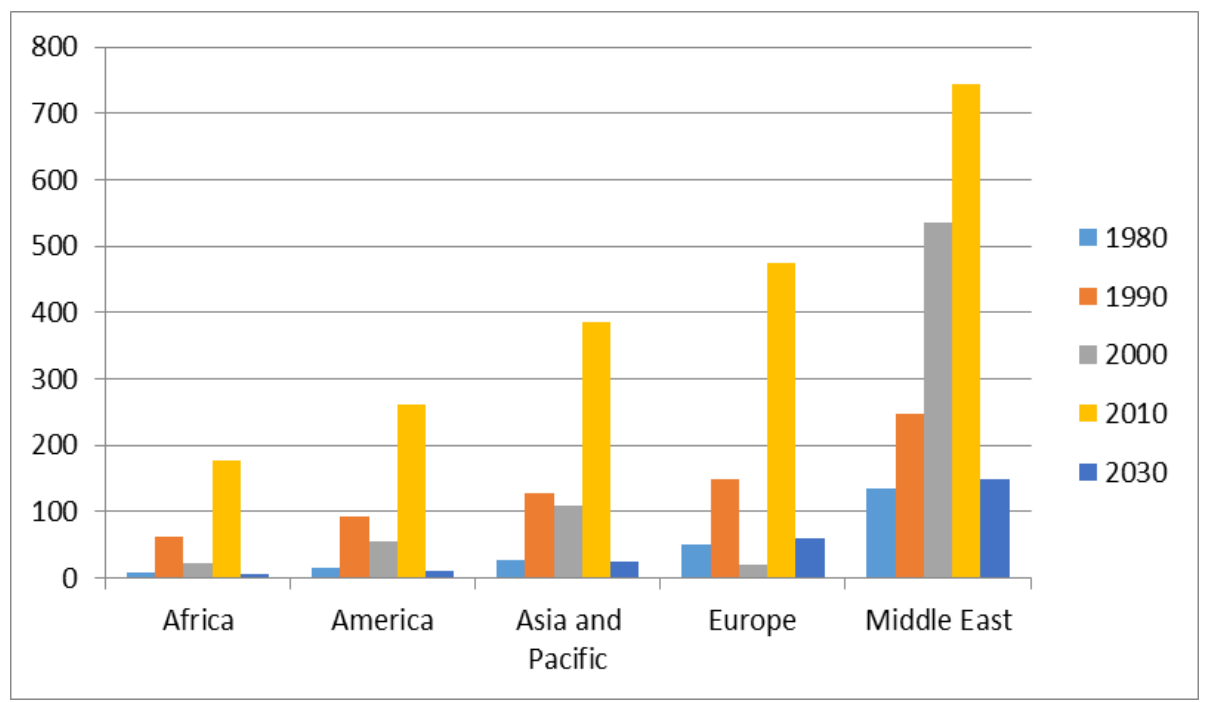

Source: UNWTO, 2014; UNWTO, 2015

The most travellers had been and are orientated mainly to the Europe, Asia/Pacific and America. Such increasing trend of visitation can be expected also in the future. Africa and Middle East are the less visited.

Third graph at Figure 4 is orientated to the passive foreign tourism that had been recorded from 1980 till assumed development to 2030. The graph shows the most travellers are from Europe, followed by Asia/Pacific and America. Such increasing trend of travelling tourists' number can be expected also in the future. On the other hand Africans and Middle East travel the least - due to the lack of basic primary needs satisfaction.

Figure 4: Passive foreign tourism (in mil. persons)

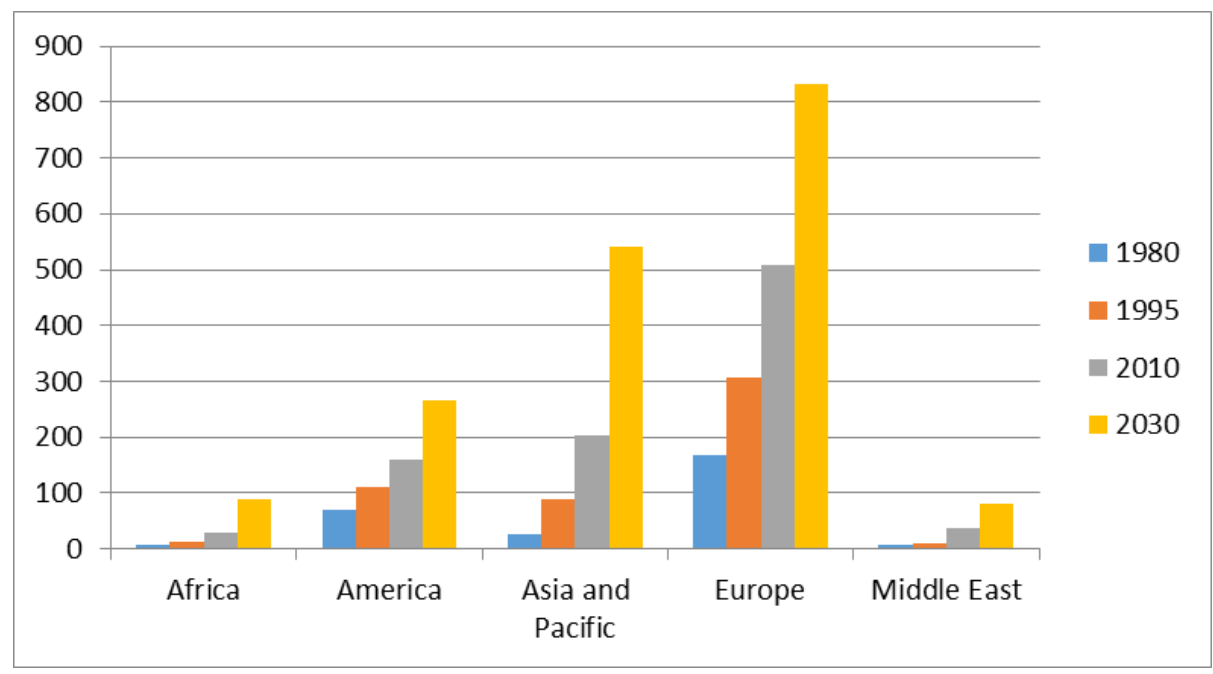

Source: UNWTO, 2014; UNWTO, 2015 
Consequently, according Figure 3 we found out most visitors is from EU countries. During the research, we confirmed it by ranking between 15 countries from the view of accommodated visitors in tourism in Slovakia in 2015, given by Table 1.

Table 1: Top 15 countries by accommodation number in 2015

\begin{tabular}{|c|c|c|}
\hline Ranking & Country & Number of guests \\
\hline 1. & Czech Republic & 509700 \\
\hline 2. & Poland & 168358 \\
\hline 3. & Germany & 158857 \\
\hline 4. & Austria & 81589 \\
\hline 5. & Hungary & 69563 \\
\hline 6. & Great Britain & 64891 \\
\hline 7. & Italy & 59294 \\
\hline 8. & Ukraine & 51591 \\
\hline 9. & USA & 40553 \\
\hline 10. & France & 37401 \\
\hline 11. & Russia & 29664 \\
\hline 12. & China & 28154 \\
\hline 13. & Romania & 27904 \\
\hline 14. & Spain & 27258 \\
\hline 15. & Israel & 22395 \\
\hline
\end{tabular}

Source: Statistical Office SR, 2016

Slovakia as a target of tourism disposes sufficient volume of accommodation capacities, but it uses them at extraordinary low level. The more important index of attractiveness evaluation from the view of satisfied demand, is coefficient ka2 (see Table 2), since ka1 index does not considers length of stay in target place, which is similarly speaking about country attractiveness and it does not consider either possible multiple reckoning of tourists in case of foreign visitors staying in more accommodation facilities during one visit of Slovakia (Debski \& Nasierowski, 2017). Table 2 illustrates attractiveness of the country from the view of quality of provided services: attractive primary and secondary offer, position and social assumptions of the country.

Table 2: Resource markets according Slovakia attractiveness

\begin{tabular}{|l|c|c|c|c|c|c|}
\hline State & $\begin{array}{c}\text { Coefficie } \\
\text { nt of } \\
\text { attractive } \\
\text { ness - } \\
\mathbf{k a}_{1}\end{array}$ & $\begin{array}{c}\text { Interpretation } \\
\text { of Slovakia } \\
\text { attractive- } \\
\text { ness - ka }\end{array}$ & $\begin{array}{c}\text { Coefficie } \\
\text { nt of } \\
\text { attractive } \\
\text { ness - } \\
\mathbf{k a}_{\mathbf{2}}\end{array}$ & $\begin{array}{c}\text { Interpretatio } \\
\text { n of } \\
\text { Slovakia } \\
\text { attractive- } \\
\text { ness - ka }\end{array}$ & $\begin{array}{c}\text { Foreign } \\
\text { represent } \\
\text { ation } \\
\text { existence }\end{array}$ & $\begin{array}{c}\text { Market } \\
\text { priority, } \\
\text { declared in } \\
\text { marketing } \\
\text { strategy }\end{array}$ \\
\hline Slovakia & 43,92 & No attractive & 131,95 & No attractive & $\mathrm{X}$ & $\begin{array}{c}\text { Primary } \\
\text { market }\end{array}$ \\
\hline $\begin{array}{l}\text { Czech } \\
\text { Republic }\end{array}$ & 4,69 & $\begin{array}{c}\text { Very strong } \\
\text { attractive }\end{array}$ & 13,2 & $\begin{array}{c}\text { Very strong } \\
\text { attractive }\end{array}$ & Yes & $\begin{array}{c}\text { Primary } \\
\text { market }\end{array}$ \\
\hline Austria & 0,87 & Low attractive & 1,76 & No attractive & Yes & $\begin{array}{c}\text { Primary } \\
\text { market }\end{array}$ \\
\hline Hungary & 0,7 & $\begin{array}{c}\text { Very low } \\
\text { attractive }\end{array}$ & 1,44 & $\begin{array}{c}\text { Very low } \\
\text { attractive }\end{array}$ & Yes & $\begin{array}{c}\text { Primary } \\
\text { market }\end{array}$ \\
\hline Poland & 0,44 & No attractive & 1,15 & $\begin{array}{c}\text { Very low } \\
\text { attractive }\end{array}$ & Yes & $\begin{array}{c}\text { Primary } \\
\text { market }\end{array}$ \\
\hline Germany & 0,19 & Very low & 0,58 & $\begin{array}{c}\text { Very low } \\
\text { attractive }\end{array}$ & Yes & $\begin{array}{c}\text { Primary } \\
\text { market }\end{array}$ \\
\hline
\end{tabular}




\begin{tabular}{|l|c|c|c|c|c|c|}
\hline Ukraine & 0,18 & $\begin{array}{c}\text { Very low } \\
\text { attractive }\end{array}$ & 0,52 & $\begin{array}{c}\text { Very low } \\
\text { attractive }\end{array}$ & No & $\begin{array}{c}\text { Primary } \\
\text { market }\end{array}$ \\
\hline Netherland & 0,12 & $\begin{array}{c}\text { Very low } \\
\text { attractive }\end{array}$ & 0,29 & $\begin{array}{c}\text { Very low } \\
\text { attractive }\end{array}$ & No & $\begin{array}{c}\text { Secondary } \\
\text { market }\end{array}$ \\
\hline Romania & 0,12 & $\begin{array}{l}\text { Very low } \\
\text { attractive }\end{array}$ & 0,28 & $\begin{array}{c}\text { Very low } \\
\text { attractive }\end{array}$ & No & - \\
\hline Italy & 0,09 & $\begin{array}{l}\text { Very low } \\
\text { attractive }\end{array}$ & 0,18 & $\begin{array}{c}\text { Very low } \\
\text { attractive }\end{array}$ & No & $\begin{array}{c}\text { Primary } \\
\text { market }\end{array}$ \\
\hline Great Britain & 0,08 & $\begin{array}{l}\text { Very low } \\
\text { attractive }\end{array}$ & 0,16 & $\begin{array}{c}\text { Very low } \\
\text { attractive }\end{array}$ & No & $\begin{array}{c}\text { Primary } \\
\text { market }\end{array}$ \\
\hline Russia & 0,04 & $\begin{array}{l}\text { Very low } \\
\text { attractive }\end{array}$ & 0,14 & $\begin{array}{c}\text { Very low } \\
\text { attractive }\end{array}$ & Yes & $\begin{array}{c}\text { Primary } \\
\text { market }\end{array}$ \\
\hline France & 0,06 & $\begin{array}{l}\text { Very low } \\
\text { attractive }\end{array}$ & 0,11 & $\begin{array}{c}\text { Very low } \\
\text { attractive }\end{array}$ & No & - \\
\hline South Korea & 0,05 & $\begin{array}{l}\text { Very low } \\
\text { attractive }\end{array}$ & 0,09 & $\begin{array}{c}\text { Very low } \\
\text { attractive }\end{array}$ & No & $\begin{array}{c}\text { Secondary } \\
\text { market }\end{array}$ \\
\hline Spain & 0,04 & $\begin{array}{l}\text { Very low } \\
\text { attractive }\end{array}$ & 0,08 & $\begin{array}{c}\text { Very low } \\
\text { attractive }\end{array}$ & No & $\begin{array}{c}\text { Secondary } \\
\text { market }\end{array}$ \\
\hline USA & 0,01 & $\begin{array}{l}\text { Very low } \\
\text { attractive }\end{array}$ & 0,02 & $\begin{array}{c}\text { Very low } \\
\text { attractive }\end{array}$ & No & $\begin{array}{c}\text { Secondary } \\
\text { market }\end{array}$ \\
\hline
\end{tabular}

Source: Pompurová, 2013

Attractiveness of Slovakia as target country of tourism is mostly influenced by position of the locality, as it is in case of primary offer of tourism. Slovakia is relatively able to satisfy the most needs of respondents that are connected to the position (transport and distance access) and primary offer of the country (see Table 3 ).

Table 3: Evaluation of perceived attractiveness

\begin{tabular}{|l|c|c|c|c|c|}
\hline Criteria & Slovakia & $\begin{array}{l}\text { Czech } \\
\text { Republic }\end{array}$ & Hungary & Poland & V4 \\
\hline Criteria connected with position of target & 69,66 & 85,27 & 90,32 & 86,91 & 79,05 \\
country: & 66,72 & 84,53 & 86,43 & 85,32 & 75,94 \\
$\quad$ - transport accessibility & 73,46 & 85,99 & 94,42 & 90,86 & 82,62 \\
$\quad$ - distance of individual centres to $\quad$ permanent residence & & & & & \\
\hline Criteria connected with social assumptions of & 62,97 & 69,09 & 70,09 & 75,79 & 67,71 \\
target country: & 65,18 & 77,23 & 80,98 & 90,89 & 74,30 \\
$\quad$ - security of visitors & 54,57 & 67,88 & 80,09 & 76,38 & 64,71 \\
$\quad$ prices & 74,25 & 76,22 & 80,88 & 78,11 & 76,32 \\
$\quad$ national cuisine & 62,30 & 75,47 & 73,63 & 95,06 & 72,78 \\
$\quad$ - attitude of local inhabitants to visitors & 89,98 & 79,03 & 65,55 & 85,53 & 83,86 \\
$\quad$ - ability of local inhabitants to & & & & & \\
$\quad$ communicate in Slovak language $\quad$ ability of local inhabitants to & 53,51 & 59,41 & 55,77 & 63,75 & 56,23 \\
$\quad$ communicate in English & 46,57 & 53,87 & 58,26 & 60,31 & 51,10 \\
$\quad$ ability of local inhabitants to & & & & & \\
$\quad$ communicate in German & 76,93 & 73,04 & 72,53 & 68,07 & 73,41 \\
\hline Criteria connected with primary offer of target & & & & \\
country: & 73,61 & 67,65 & 81,34 & 79,37 & 75,26 \\
$\quad$ - climate & 89,95 & 86,31 & 89,21 & 85,61 & 88,40 \\
$\quad$ nature & 79,67 & 74,90 & 68,82 & 62,32 & 75,01 \\
$\quad$ - history & 84,11 & 79,73 & 74,96 & 68,29 & 79,60 \\
\hline
\end{tabular}




\begin{tabular}{|l|l|l|l|l|l|}
\hline - culture & 70,37 & 71,19 & 63,79 & 64,68 & 68,71 \\
- organized events & 67,94 & 69,27 & 60,71 & 66,24 & 66,73 \\
- traditions & 66,15 & 66,74 & 76,03 & 70,49 & 68,65 \\
\hline Criteria connected with secondary offer of & 64,54 & 69,95 & 71,13 & 78,08 & 68,90 \\
target country: & & & & & \\
- information about tourism centres & 58,44 & 73,81 & 71,84 & 77,26 & 66,15 \\
- transport infrastructure & 52,94 & 69,95 & 69,64 & 71,73 & 61,73 \\
- buying possibilities & 64,56 & 67,40 & 72,43 & 71,42 & 68,25 \\
- sports and recreation & 71,57 & 75,34 & 81,84 & 90,56 & 77,65 \\
- parks, aqua parks & 69,83 & 70,24 & 69,18 & 86,65 & 72,90 \\
- amusements & 64,83 & 65,10 & 64,47 & 64,31 & 63,34 \\
- accommodation & 68,93 & 71,07 & 74,45 & 86,41 & 73,41 \\
- hospitality & 67,86 & 71,05 & 74,55 & 86,49 & 72,62 \\
\hline Sum & 68,70 & 71,59 & 72,61 & 74,75 & 70,29 \\
\hline
\end{tabular}

Source: Pompurová, 2009

In the frame of individual criteria, natural beauties of the Slovakia are relatively most-attractive due to the geomorphologic characteristics, fauna and flora, closeness of the lakes and rivers, mineral and thermal sources, waterfalls, caves, etc. Those are supported by sports and recreation units and activities, where for example tourist tracks, ski-lifts and cable cars can be included, as well as ski cross country tracks, ski slopes, cycling tracks, horse riding, fitness centres, swimming pools, saunas, fishing, hunting etc., followed by architectonic monuments, for example palaces, chapels, castles, mansions, churches, monasteries, technical works. Accommodation units, support their using as for example capacity, number and quality of hotels, tourist accommodation, pensions, camps and private accommodation. Transport access of the country, resp. individual centres of the tourism and security of the visitors and their property provide support also. In this connection Slovakia can be considered as universally attractive target country, since the country has natural, cultural and infrastructural utility for the visitors, which are generally attractive and proper for development of various types of tourism, as for example recreation, sports, adventurous, cultural and learning tourism. From the other side the less suitable demands of potential visitors in V4 are possibilities and facilities of fun and social services, purchases, as well as ability of the Slovakian inhabitants to communicate in foreign language (English or German).

\section{Discussion}

Tourism can be considered as one of the main factors that conditions and stimulates economic development of the country. According Hrabovská (2014) employment of domestic inhabitants is increasing in tourism and connected sectors, as well as inhabitants incomes due to the development of business activities in tourism, life standard of inhabitants, improving of local economy, investment, development and expenses from infrastructure. From the presented longterm prognosis of whole world character there is expected further increase of tourism, either in active or in a passive way. The coordinated process of tourism management helps to increase country competitiveness at the European or world market of tourism. It is supported also by active state policy of tourism, further good infrastructure, qualified working power and helpfulness of inhabitants towards tourists (Provenzano \& Baggio, 2017; Camisón \& Forés, 2015).

Tourism prediction can be included to several trends, having influence to the demand in tourism. Mainly increasing of average income and decrease of global poverty are resulting in growing incomes of inhabitants. Also in the future there is expecting still growing population with higher 
incomes yet to approximately 4.9 milliard people in 2030. The greatest growth of such population is expected in Asia with significant importance and influence to the tourism development. Also new destinations are becoming available, searching by higher mentioned segments. From marketing perspective, tourism development can benefit from improved market positioning. The result of the improved market positioning can be caused when its consumers become aware of the social and environmental sensitivity of the organization (McCool et al., 2001). On the other hand, presently there is still higher need to provide political, economic and social stability with aim to secure all tourists. Moreover, tourism is controlled by digital technologies, presenting real revolution in the sector. In addition, health and healthy living style become one of the factors, influencing future orientation of the tourism offer.

\section{Conclusions}

Global tourism will be still growing together with world prosperity and wealth fare and therefore there is necessary to provide also its sustainability. It means economic, social and environmental pillars must be in balance with a goal to provide long-term sustainable development of tourism. It demands participation of all relevant stakeholders, as well as strong political leadership. Tourism sustainability has competitive advantage through creating of the competitive environment.

This study argues attractiveness of Slovakia is perceived from the side of inhabitants in V4 as target place since tourism is considered higher than its attractiveness from the view of satisfied demand. There is therefore space for visitation increasing, as well as improving of Slovakia perception as target country for tourism. The research provides contribution to the literature from the view of operational use in practice, and it could serve as tool for development of academic and managerial area by following positives and provided services in tourism, such as attractive primary and secondary offer, position and social assumptions of the country. Tourism development can be researched in the future from the view of individual factors.

\section{Acknowledgment}

This research presents partial results of the research projects VEGA No 1/0651/18.

\section{References}

Blumenberg, E., Pierce, G. (2017). The drive to work: The relationship between Transportation access, Housing assistance, and Employment among Participants in the welfare to work voucher program, Journal of Planning Education and Research, 37 (1), 66-82.

Borowiecki, K.J., Castiglione, C. (2014). Cultural participation and tourism flows: An empirical investigation of Italian provinces, Tourism Economics, 20 (2), 241-262.

Camisón, C., Forés, B. (2015). Is tourism firm competitiveness driven by different internal or external specific factors? New empirical evidence from Spain, Tourism Management, 48, 477-499.

Csikósová, A., Antošová, M., Čulková, K. (2014). Strategic aspects of business in context of regional development, Ostrava: VŠB-TU.

Das, D., Hussain, I. (2016). Does ecotourism affect economic welfare? Evidence from Kaziranga National Park, India, Journal of Ecotourism, 15 (3), 241-260. 
Debski, M., Nasierowski, W. (2017). Criteria for the selection of tourism destinations by students from different countries, Foundations of Management, 9 (1), 317-330.

Dymond, S. (1997). Indicators of sustainable tourism in New Zealand: A local government perspective, Journal of Sustainable Tourism, 5 (4), 279-293.

Dwyer, L., Forsyth, P. (2008). Economic measures of tourism yield: What markets to target? International Journal of Tourism Research, 10 (2), 155-168.

Elkington, J. (2004). Enter the triple bottom line. In The Triple Bottom Line, does it all add up? Assessing the Sustainability of Business and CSR, A. Henriques and J. Richardson, Eds. pp. 1-16. London: Routledge.

Hrabovská, Z. (2014). Tourism and regional growth in Visegrad countries. In SGEM 2014, International Multidisciplinary Scientific Conferences on Social Sciences and Arts, Proceedings, Albena, Bulgaria, 01-10 September 2014; pp. 843-849. Bulgaria, Sofia: STEF92 Technology.

Hughes, G. (2002), "Environmental indicators", Annals of Tourism Research, 29 (2), 457-477.

Kock, F., Josiassen, A., Assaf, A.G. (2016). Advancing destination image: The destination content model, Annals of Tourism Research, 61, 28-44.

Liu, C.M., Zhang, R.Y., Wang, M., Xu, J. (2018). Measurement and prediction of regional tourism sustainability: An analysis of the Yangtze River economic zone, China, Sustainability, 10 (1), 1-20.

McCool, S., Moisey, N., Nickerson, N. (2001). What should tourism sustain? The disconnect with industry perceptions of useful Indicators, Journal of Travel Research, 40 (2), 124-131.

Molokáč, M., Kršák, B., Sidor, C. (2016). Models for mapping tourists (regarding surrounding, E-Review of Tourist Research, 13 (5-6), 550-560.

Moscardo, G., Murphy, L. (2014). There is no such thing as sustainable tourism: Reconceptualizing tourism as a tool for sustainability, Sustainability, 6 (5), 2538-2561.

Petrović, M.D., Vujko, A., Gajić, T., Vuković, D.B., Radovanović, M., Jovanović, J.M., Vuković, N. (2018). Tourism as an approach to sustainable rural development in postsocialist countries: A comparative study of Serbia and Slovenia, Sustainability, 10 (1).

Pizam, A., Smith, G. (2000). Tourism and terrorism: A quantitative analysis of major terrorist acts and their impact on tourism destinations, Tourism Economics, 6 (2), 123-138.

Pompurová, K. (2013). Attractiveness of Slovakia as target place of tourism (in Slovak), Banská Bystrica: Univerzita Mateja Bela.

Pompurová, K. (2009). Searching of locality attractiveness - challenge for management of target cities (in Slovak). Katowice: Uniwersytet Śląski.

Provenzano, D., Baggio, R. (2017). The contribution of human migration to tourism: The VFR travel between the EU 28 member states, International Journal of Tourism Research, 19 (4), 412-420.

Statistical Office SR. Informative report 2016 (in Slovak), available at https://slovak.statistics.sk/wps/ wcm/ connect/a6b64a48-c878-4b95-883abcbb2445948a/Satelitny_ucet_cestovneho_ruchu_SR_2016 .pdf? MOD=AJPERES

Stoddard, J.E., Pollard, C.E., Evans, M.R. (2012). Triple Bottom Line: A Framework for sustainable tourism development, International journal of hospitality and tourism administration, 13 (3), 233-258.

Tang, C.M.F., King, B., Pratt, S. (2017). Predicting hotel occupancies with public data: An application of OECD indices as leading indicators, Tourism economics, 23 (5), 1096-1113. 
Torres-Delgado, A., Saarinen, J. (2014). Using indicators to assess sustainable tourism development: A review, Tourism Geographies, 16 (1), 31-47.

Tudorache, D.M., Simon, T., Frent, C., Musteaţă-Pavel, M. (2017). Difficulties and challenges in applying the European Tourism Indicators System (ETIS) for sustainable tourist destinations: The case of Brasov county in the Romanian Carpathians, Sustainability, 9 (10), 1-19.

Vystoupil, J., Kasagranda, A., Šauer, M. (2016). Functional-spatial typology of tourist resorts in Czechia and Slovakia, Geografical journal, 68 (2), 171-192.

Willard, B., Elkington, J. (2002). The Sustainability Advantage: Seven Business Case Benefits of a Triple Bottom Line. Canada: New Society Publishers.

World Tourism Organization UNWTO (2015). UNWTO Annual Report 2014, available at www2.unwto.org/ annualreport2014

World Tourism Organization UNWTO (2015). Tourism Highlights, available at www.e-unwto.org/doi/pdf/ $10.18111 / 9789284416899$ 